\title{
Art and Science: Articulating a Contemporary Dialogue Using the Perspective of the Renaissance (Relation Galileo-Cigoli Rediscovered)
}

\author{
By Marcos Cesar Danhoni Neves* \\ Josie Agatha Parrilha da Silva ${ }^{+}$
}

By two research groups, INTERART (Interaction between Art, Science and Education: Dialogues in Visual Arts) and PEFAHC (Research in Physics Teaching, Astronomy and History of Science), started five years ago, motivated by the celebration of the 400 years of the invention of the telescope, a dialogue that became permanent at undergraduate and postgraduate with our inquiries about the development of art and science from Renaissance to Contemporary. We take as a basis the relationship between Galileo Galiei (the "scientist") and Lodovico Cardi's Cigoli (the "Artist"). By analyzing the construction of the works "Siderius Nuncius," "Madonna Assunta" (fresco at the Paolina's dome in Santa Maria Maggiore, Rome) and "Discorsi Intorno alle Macchie Solari e loro Accidenti" discovered an intercultural universe where art and science were linked in a harmonious and indissoluble way. Thus, the old nomenclature: artist and scientist should be changed to "scientist-artist" and "artist-scientist." This reflection was inaugurated with the "Paranaense's Workshops of Art-Science/International Meeting on Art-Science" to provide space for interaction between art and science in dialogue with different audiences. In this trajectory we wrote several books, built blogs and created the "Brazilian Review of Art-Science," a magazine devoted to the permanent art-science dialogue. Furthermore, we initiated a more permanent and educational vision when we contribute to the creation of the Bachelor's Degree in Visual Arts at the State University of Maringá and introduced a discipline named "Intercultural Dialogues I and II;" and, similarly, in the Bachelor's Dg. in Visual Arts from the State University of Ponta Grossa the discipline "Dialogues Art-Science." In the stricto sensu academic area, we create, in the PostGraduate (Masters, PhD) in Science Education and Technology, Federal Technological UniversityParaná, Ponta Grossa, a research's line for "Art, Science and Teknè: intercultural dialogues" with six postgraduate students working on research of different art-science relationship.

\section{Introduction}

The current analysis continues on the investigation reported at the XVIII Jornadas de Epistemologia y Historia de la Ciencia ${ }^{1}$ with the title "Da Lua de da Vinci, Cigoli e Galilei: da corrupção do céu e de seu matrimônio com a Terra." In 2007, investigations focused on the use of the chiaroscuro to define the new perspective mode and the discoveries of Galileo with his telescope and published in his book

\footnotetext{
* Professor, Laboratory of Visual Creation, State University of Maringá, Brazil.

${ }^{\dagger}$ Associate Professor, Department of Arts, State University of Ponta Grossa, Brazil.

1. La Falda, XVIII Jornadas de Epistemologia y Historia de la Ciencia (XVIII Conference on Epistemology and History of Science), 2007. Retrieved from goo.gl/BX3f8D.
} 
Sidereus Nuncius and sometimes painted by his friend Lodovico Cardi, a.k.a. Cigoli, from the Accademia Del Disegno. Current paper is an in-depth investigation on the painting of The Assumption of the Virgin from the dome of the papal basilica Santa Maria Maggiore in Rome and analyzes the frequent correspondence between Cigoli and Galileo on the debates with Jesuits and other critics of Copernicanism and the Genesis of the Istoria e dimostrazione sulle macchie Solari e loro accidenti, in which Cigoli had a heavy hand in the text and in the painting of sun spots published in the 1612 first edition of the book.

In 2007 the Times published the article The Galileo Sketches that turned the Universe on its head: Moon drawings lost for 400 years, on the finding of five waterpaintings of the moon (Figure 1) which foregrounded Galileo Galilei' s Sidereus Nuncius, published in Venice in 1610, dealing with the telescope observations made by the Italian philosopher. ${ }^{2}$ The illustrations were discovered in Argentina in the archives of an Italian migrant family and which were later sold to a New York antiquarian. The authenticity of the water-colors was confirmed by Prof. Horst Bredekamp, ${ }^{3}$ of the University of Humboldt in Berlin, Germany, and by Prof. William Shea, of the University of Padua, Italy.

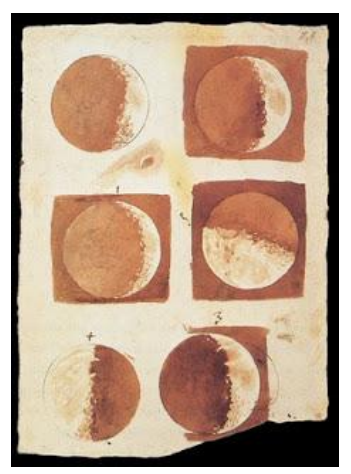

Figure 1. Watercolors of the Moon

It is still undecided whether the watercolors were painted by Galileo himself or by his great friend and Florentine painter Lodovico Cardi, a.k.a. Cigoli.

The colored paintings show the moon and details of its surface, with craters and mountain ranges, by using the chiaroscuro technique underscoring deep ochre and brownish colors. The undecided authorship is due to the friendship between the two, which was interrupted when Cigoli died in 1613, three years after the publication of Sidereus Nuncius and one year after Istoria e Dimostrazioni intorno alle Macchie Solari. According to Bredekamp, ${ }^{4}$ the analysis of the

2. Richard Owen, The Galileo Sketches that turned the Universe on its head (New York: The Times, 2007). Retrieved from goo.gl/cwhlRO. [Accessed: 20 April 2012]

3. Horst Bredekamp, "The Context of the Artists," Science in Context 14, no. S1 (2001): 153-192. Retrieved from goo.gl/OqcpSz. [Accessed: 20 April 2012]

4. Bredekamp, "The Context of the Artists," 2001. 
watercolors seem to show an analogy to sketches of the younger Galileo when he was a member of the Florentine Accademia del Disegno.

On the fourth centenary of the "invention" of the telescope and the publication of the Sidereus Nuncius, the "Research Group for the Teaching of Physics, Astronomy and the History of Science" is endeavoring to make all efforts for the undertaking of several activities (exhibitions, workshops, academic papers) on the subject. The activities are a great help for the understanding, foregrounding and broadcasting the deep links between Art and Science defined by Koyré's 1966 work Études d'histoire de la pensée scientifique. ${ }^{5}$ It should be emphasized that the current paper is the result of research work from primary sources undertaken in London (Warburg Institute), Rome (Università La Sapienza), Naples (Istituto Italiano per gli Studi Filosofici) and Florence (Istituto e Museo di Storia della Scienza - Museo Galileo).

During the last five years and after the performance of four workshops titled Workshops Paranaenses de Arte-Ciência (with two international editions: International Meeting on Art-Science), three exhibitions on "Four hundred years after the invention of the telescope and developments in Art," organization and publication of books (Da Terra, da Lua e Além [From the Earth, Moon and Beyond], with two editions; Da Lua Pós-Copernicana [Post-Copernican Moon]; Arte e Ciência: um encontro interdisciplinar [Art and Science: An interdisciplinary encounter]), and other research works prepared for several Brazilian and international events, the authors are convinced that the painting The Assumption of the Virgin is a radical codex of Copernican ideas. ${ }^{6}$ The latter was consolidated by "lynxes" and by Galileo's proposal to force the Catholic Church to accept the tenets of new science.

Current research investigates the relationship between Art and Science during the Renaissance when a close link is extant between the two fields of knowledge and, in a special way for the current paper, between Cigoli and Galileo, their two exponents. The contributions are foregrounded on the Copernican vision of the Earth, the discovery of the moon's craters painted by Cigoli in the dome of the basilica Santa Maria Maggiore in Rome and the close collaboration in the observations of the spots discovered on the sun's surface. The fresco on the dome of Santa Maria Maggiore shows the moon under the Virgin's feet, a common representation in Christian iconography. The uncommon thing is that the immaculate figure is supported by a moon full of craters, or rather, a post-Copernican moon and thus spotted. This contrasts the "perfect" moon, smooth and spherical, as the Peripathetics and

5. Alexander Koyré, Etudes d'Histoire de la Pensée Scientifique (History of Scientific Thought Studies) (Paris: Presses Universitaires de France, 1966).

6. Marcos Cesar Danhoni Neves, \& Josie Agatha Parrilha da Silva, Disturbing the Perspective: the new post-Copernican moon of Galileo and Cigoli. International Conference "Science \& Democracy," Napoli, Italy, 2008. 
Thomists conceived it. The difference lies in the description of the wrinkled moon, full of craters, as Galileo described it in Sidereus nuncius. ${ }^{7}$

Galileo and Cigoli were friends since the period in which they worked at the Accademia del Disegno di Firenze and shared scientific knowledge which contributed towards the new artistic representation (the cratered moon and the spotted sun). Galileo studied painting and delved into studies on the composition of the moon, planets and the sun and their movements. ${ }^{8}$ Most studies were registered in sketches and in watercolor paintings.

Galileo Galilei not only improved on the telescope, called perspicillum, but also observed what would be new discoveries at that time, or rather, Jupiter' $\mathrm{s}$ four satellites, the surface of the moon full of craters, planetary nebula, the phases of Venus, the strange morphology of Saturn. The above occurred because of the perspective mode he acquired at the Accademia del Disegno and because of his friendship with great Renaissance artists such as Cigoli, Passignano, Coccapani and others, who were conspicuous in the history of Art.

Current paper aims at underscoring the relationship between Art and Science in the Renaissance by investigating Galileo's and Cigoli's works, especially focused upon as from the 1930s when the cratered moon in the dome of the Pauline Chapel in the basilica of Santa Maria Maggiore was rediscovered after the restoration work on Cigoli's frescos. The paper also aims at presenting the discovery of the cratered moon and its repercussion on the scientific community; analyzing Cigoli's frescos within their artistic and scientific aspects with new and relevant contributions and speculations; explaining the Cigoli-Galileo correspondence and providing a translation into Portuguese of the letters between the two men.

In the current paper, a summary of a doctoral thesis and a forthcoming book on the subject starts with the chapter "The End" which contains the rediscovery of the cratered moon on the fresco of the Pauline Chapel and the context experienced during the 1930s to the present. The middle section of the book analyzes the representation of the cratered moon. The last chapter, called "The Beginning, " brings forth the Cigoli-Galileo relationship through their letters and other documents. The subjective factor of their friendship is presented in a dramatic and definitive form. In fact, it will form Galileo's second great astronomical contribution for the new science: the treatise on the sunspots.

7. Galileo Galilei, Mensagem das Estrelas (Message of the Stars) (Rio de Janeiro: Museu de Astronomia e Ciências Afins/Salamandra, 1987).

8. Galileo Galilei, Istoria e Dimostrazioni Intorno alle Macchie Solari (History and Demonstrations Around Sunspot) (Roma: Edizioni Theoria, 1982). 


\section{What Does the Fresco The Assumption of The Virgin in the Church of Santa Maria Maggiore Hides?}

Masaccio's fresco The Holy Trinity (1426-28), a masterpiece of Florentine Renaissance art, stands on the wall of the left aisle of the basilica Santa Maria Novella (Figure 2). The computer program "Empire of the Eye: the art of illusion," of the National Gallery in Washington, dedicated one of its sketches to the analysis of this artistic work. The series of illustrations in Figure 3 visualizes the painting from different perspectives, which includes the inside one.

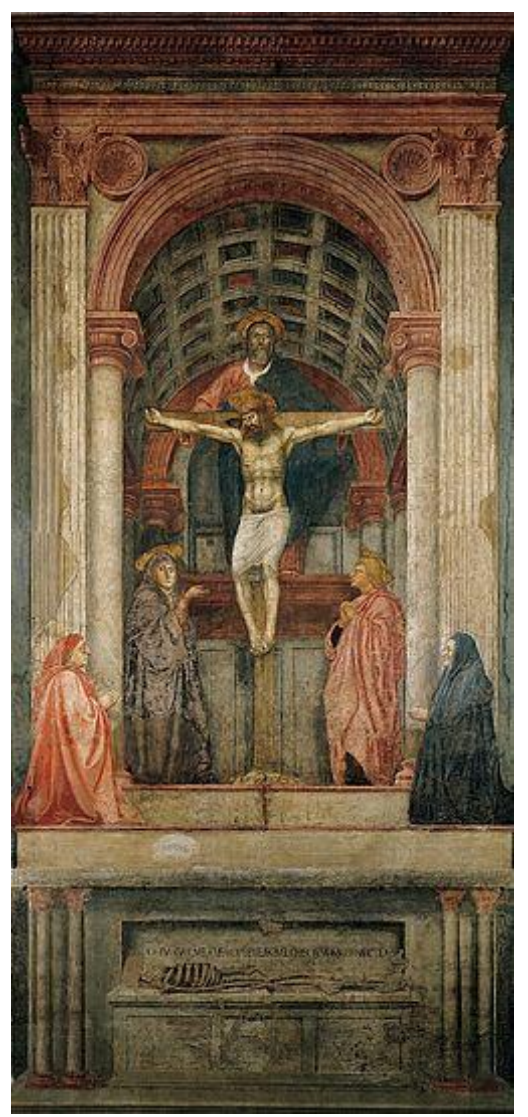

Figure 2. The "Holy Trinity," by Masaccio

We would like to recall the iconographic and iconological analysis previously given on the fresco The Assumption of the Virgin by Lodovico Cardi ${ }^{9}$ on the dome in Santa Maria Maggiore. One's physical presence in the church provides a unique and crucial perception of Cigoli's work and on Galileo's reflections on the new post-Copernican science. This is especially true when one takes into consideration the perspective that shocks the eyes, its illusion and the establishment of a planetary and heliocentric vision of the universe in

9. Danhoni Neves, \& Silva, Disturbing the Perspective:. 
a temple where geocentrism and a dogmatic vision of the earth predominated. A small telescope (Figure 4) was employed to analyze Cigoli's work from several approaches and to contrast it with the figures shown in the bibliography.

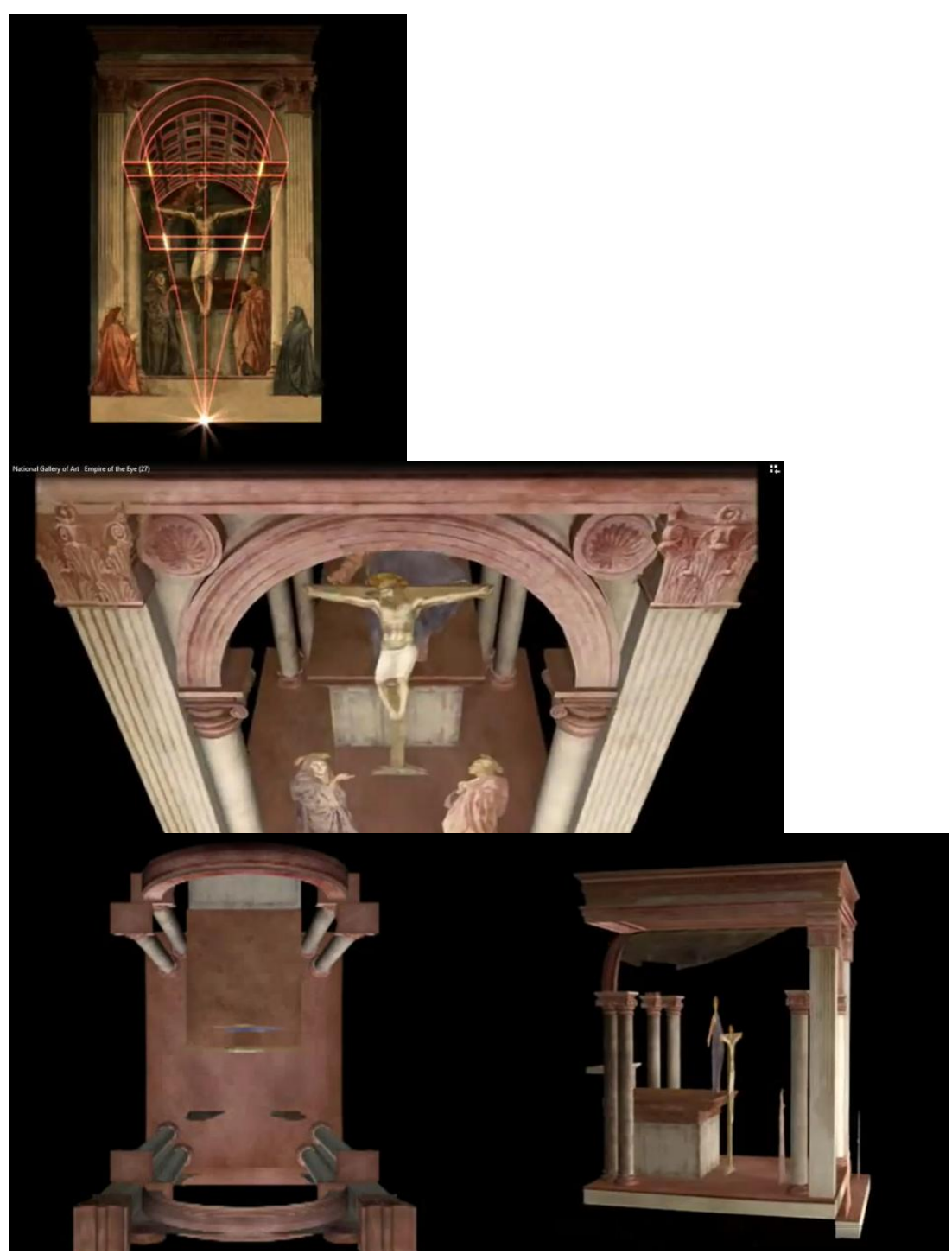

Figure 3. Series of Images on Masaccio's "Holy Trinity" by the Computer Program "Empire of the Eye," of the National Gallery

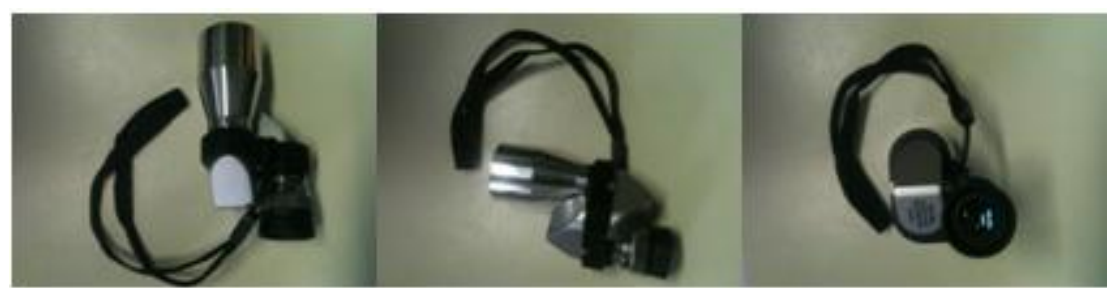

Figure 4. A Small Telescope 
A detail calls one's attention at the Pauline Chapel. When one looks at the inside of the dome, a "deformation" is perceived as lookers displace themselves on the pavement and raise their eyes in the direction of Cigoli's symbolic sky. The photographs reproduced in Figure 5 show the manner that the painting is beheld by the lookers. The moon's geometry changes, or rather, the use of anamorphism for the creation of tridimensionality of the cratered moon is evident. The dome transforms itself into an immense "planetarium" with the moon in the foreground, a homage to Galileo's Sidereus nuncius.
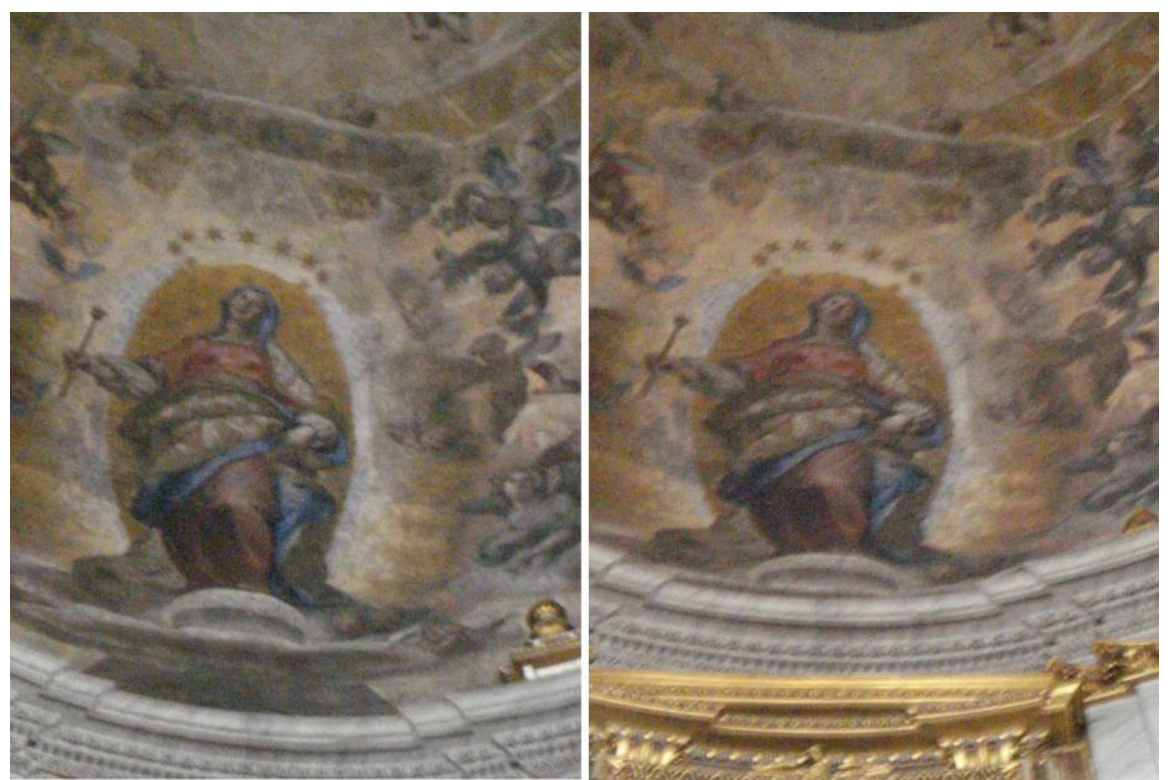

Figure 5. Photos Taken from the Ground Pavement of the Pauline Chapel in Santa Maria Maggiore, Looking in the Direction of the Inner Dome where the Painting of the Assumption Is Painted

When a resource analogous to that employed in "Empire of the Eye" is employed, coupled to programs CORELDRAW and PAINT, the fresco of Cigoli's Assumption is deconstructed to find the lost elements which in current research are called the Cigoli-Galileo Codex. When the figure of the Virgin is removed from its background, we will find what is represented in Figure 6. It reveals that the oval form with heavy orange tones is the sun brought about through the displacement of the Virgin. Needless to say, it cannot be otherwise since the Virgin is that represented in the Book of Revelation which describes the Woman with the sun behind her and the moon under her feet. The Immaculate Virgin has her feet firmly planted on a moon which is not Aristotelic or Thomistic anymore but on a maculated moon, as described by Galileo in Sidereus nuncius. She is even in front of a sun which is also maculated or spotted, as described by Galileo in his Istoria $e$ Demostrazione sulle macchie Solari e loro accidenti. 

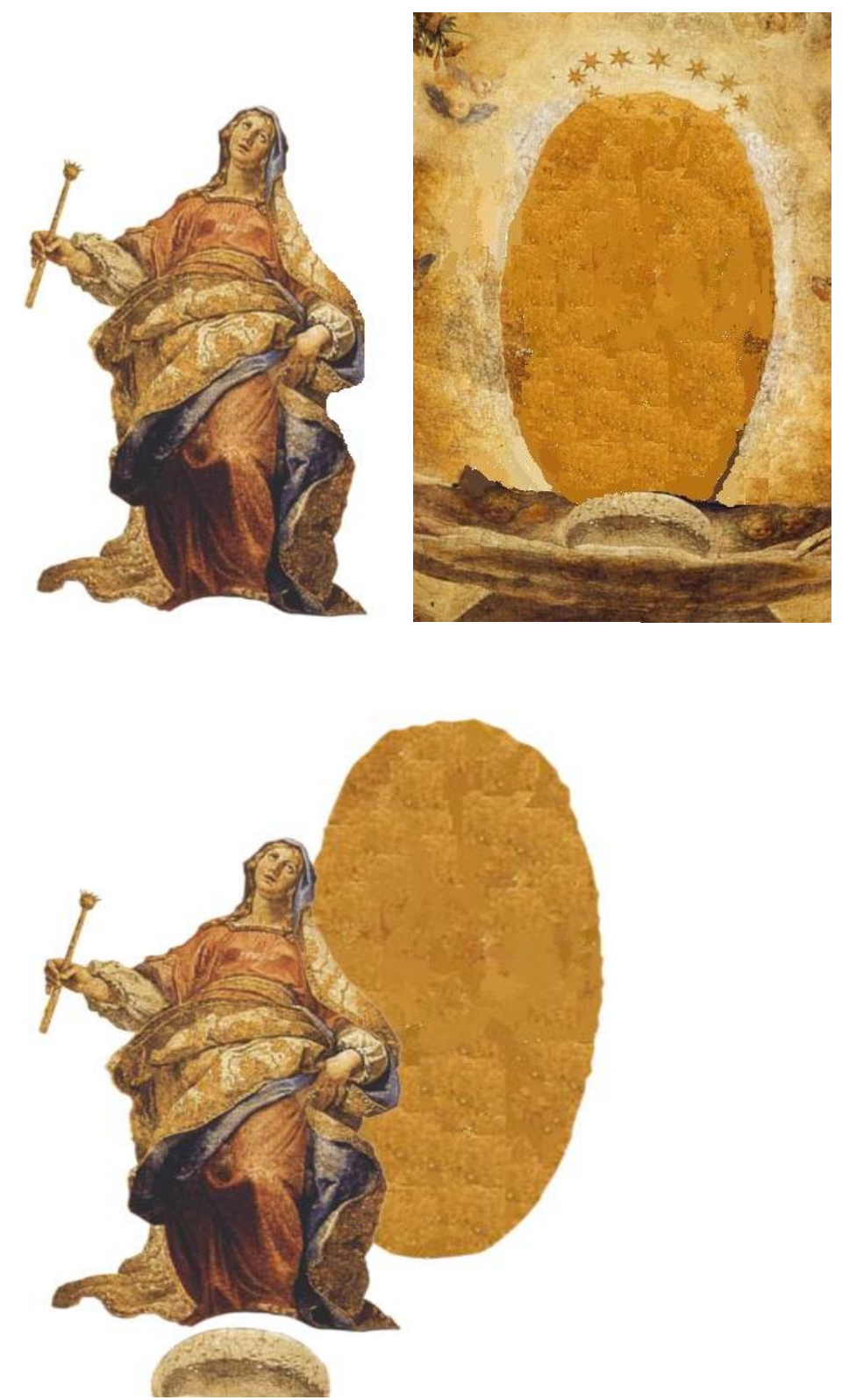

Figue 6. The Displaced Virgin

When the ring of stars in the Virgin's crown is expanded into a wider space (Figure 7), the true essence of the Virgin is revealed, or rather, she becomes the spectator of the immense heliocentric universe of Nicholas Copernicus's De Revolutionibus orbium coelestium, coupled to the discoveries published in the Sidereus nuncius and in the Trattato delle macchie solari e loro incidenti. 


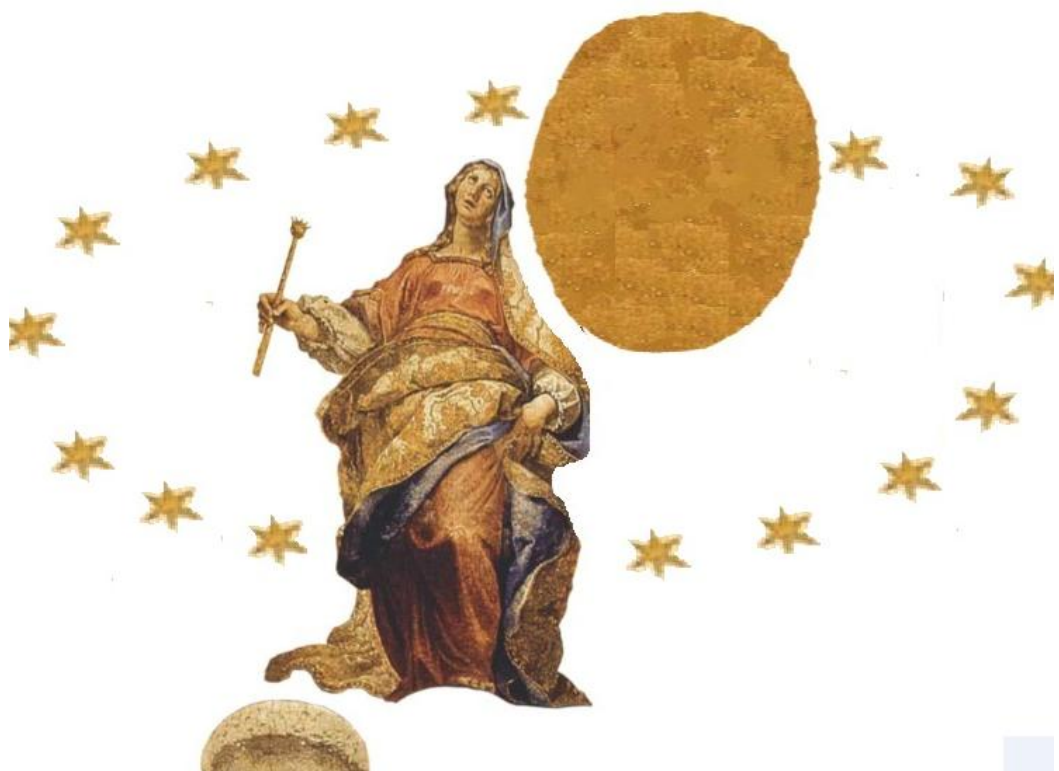

Figure 7. The Virgin with the Displacement of the Sun and the Moon, Coupled to the Amplification of the Crown of Stars: The Heliocentric Madonna

By means of the software ANAMORPH.ME what the figure above shows is now made clear (Figure 8).

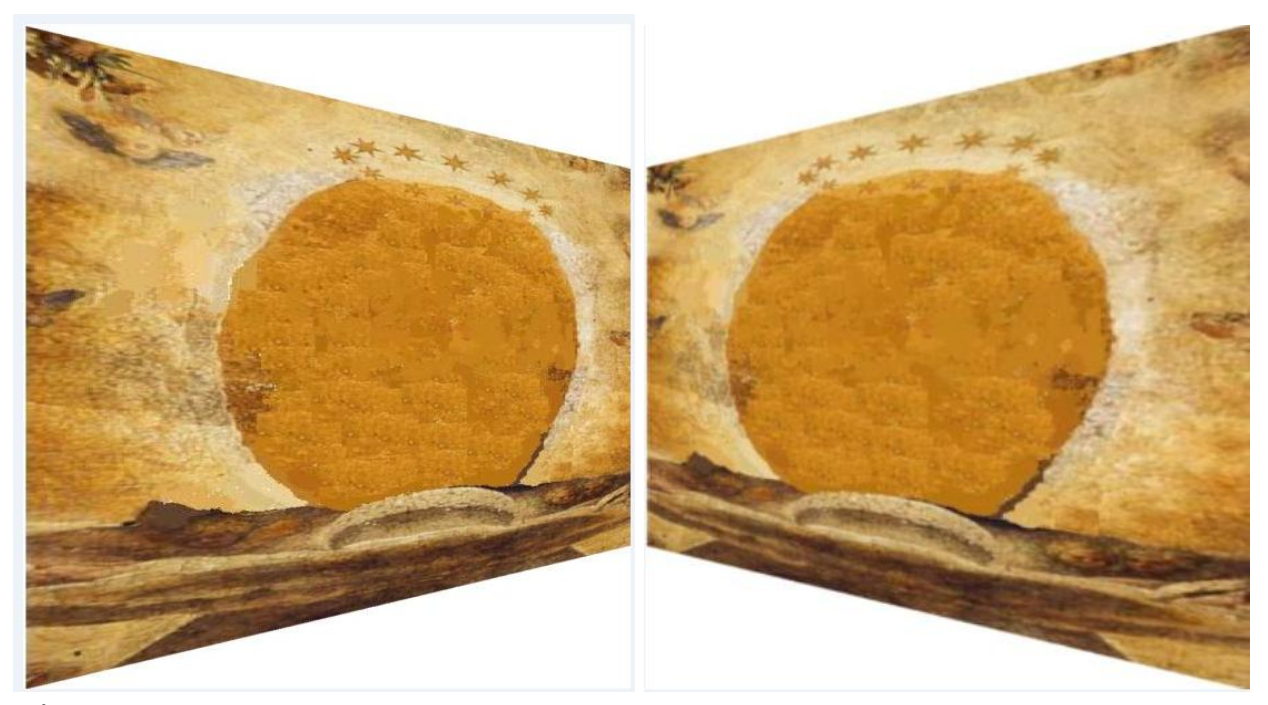

Figure 8. Cigoli's Sun, by ANAMORPH.ME

Figure 9 focused on the moon, shows that the perfection status of the Immaculate Virgin hid the sun spots. 


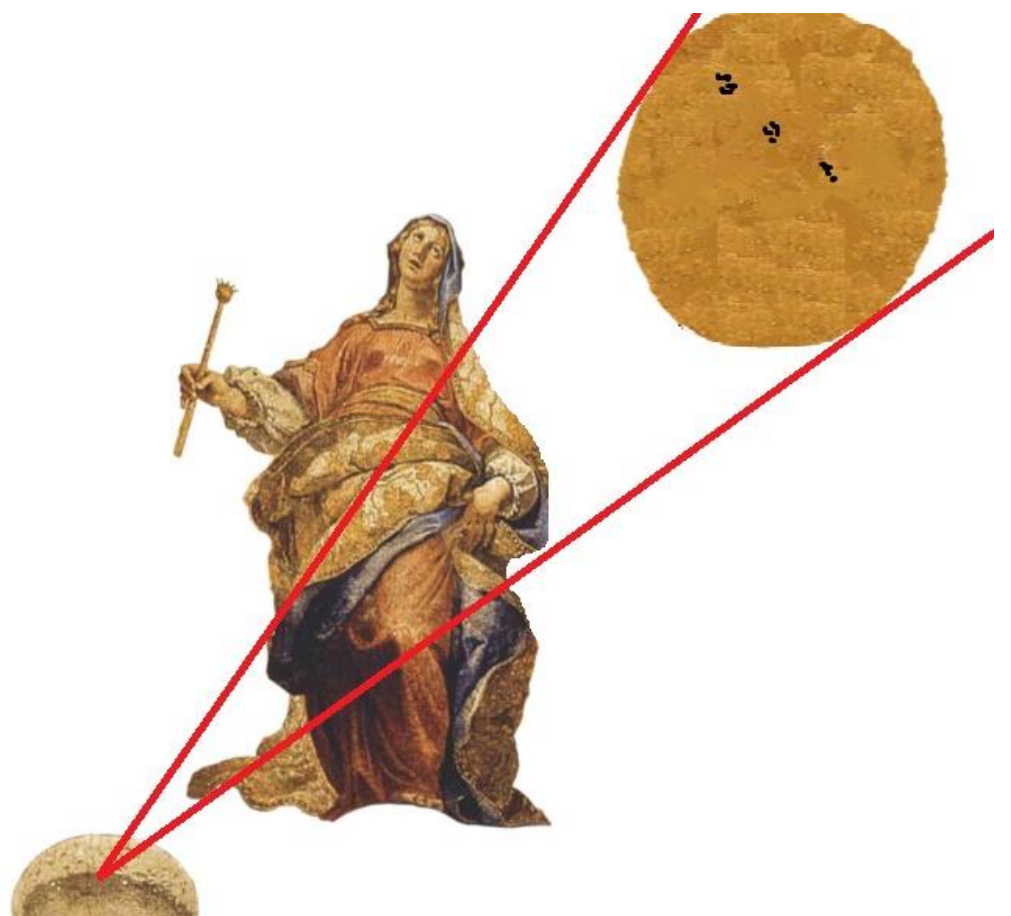

Figure 9. The Displaced Elements and the Sunspots

The letters between Cigoli and Galileo show the dire task in the execution of the fresco in the church of Santa Maria Maggiore and in the telescopic discoveries by Cigoli, Galileo, Passignano and others. This is due to the fact that envy had an important role within an environment darkened and encumbered by possibilities of accusations of heresy. Cigoli even asks for Galileo's help so that the latter may provide him arguments to show that paintings are superior to sculptures. He executes a painting, now lost, whose sketches may be found in the Galleria degli Uffizzi, in Florence, under the title "Trionfo della Virtù sull'Invidia" (Figure 10). The remarkable factor is that the "model" for this painting and that of the Virgin in Rome probably was the same woman.

Through the same methods used in "Empire of the Eyes" (Figure 11), the Virgin is unclothed and Virtue is clothed. The gaze, the height of the breasts, the same format and placing seem to show without any doubt that Virtue and the Virgin feature the same representation. However, the Codex may signal a warning: Can it be possible that a lay figure posits itself in the immensity of a sacred dome !?! 


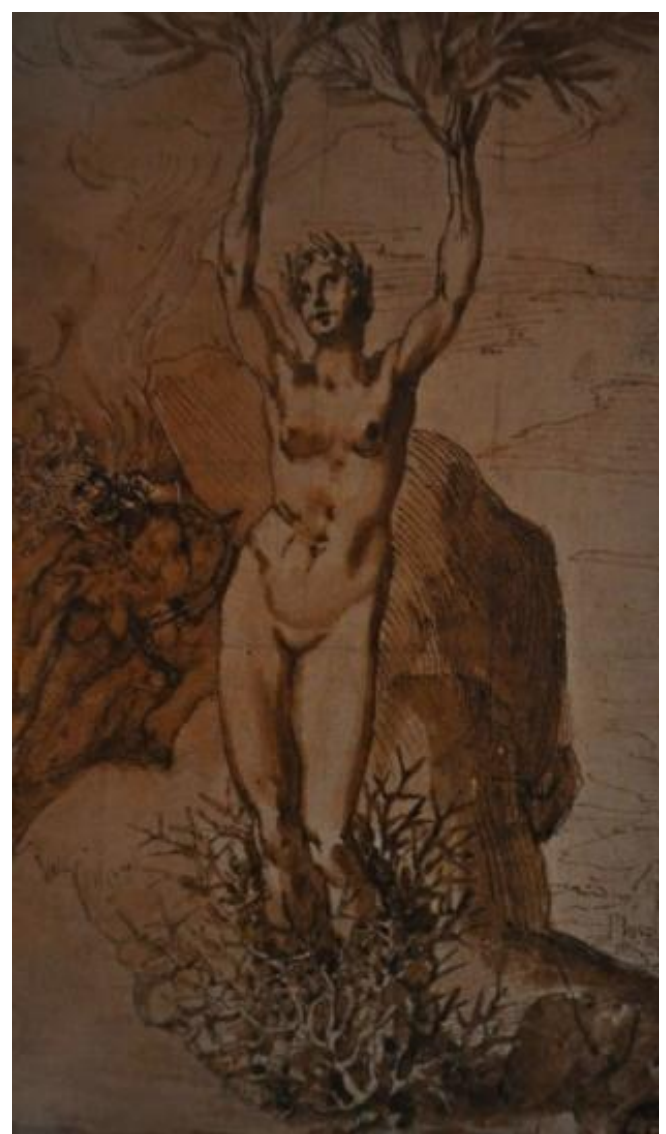

Figure 10. Il Trionfo della Virtù Sull'invidia [The Triumph of Virtue on Envy]

Another element in the Cigoli-Galileo Codex is the representation of the mythological monster that lies at the base of the cloud-moon-Virgin-sun complex and supports its structure. It is a curled serpent with the head of a dragon (Figure 12). Most probably, the serpent and the dragon in a mixed symbol of a mythological stance, represents knowledge and the danger brought about by its construction, as a hidden representation of Cigoli's artistic work.

Such a tradition of allegories may also be extant in the theme under discussion. It is enough to remind oneself of Titian's "Allegory of Prudence" or the "Allegory of Time" (Figure 13). ${ }^{10}$ Figure 14 shows a series of displacements and an "emersion" of figures which are believed to be lynxes oozing forth from the cloudy vapors below the moon. The figure may also be an allusion to the mythical monster Cerberus encountered in Dante's Divine Comedy (Figure 15). In fact, Galileo and Cigoli highly appreciated the poet of the Inferno.

10. Erwin Panofsky, Significado nas Artes Visuais (Meaning in the Visual Arts), trans. M. C. F. Keese, and J. Guinsburg, 3 ${ }^{\text {rd }}$ edn. (São Paulo: Perspectiva, 2007). 
Vol. 4, No. $3 \quad$ Neves et al.: Art and Science: Articulating a Contemporary...

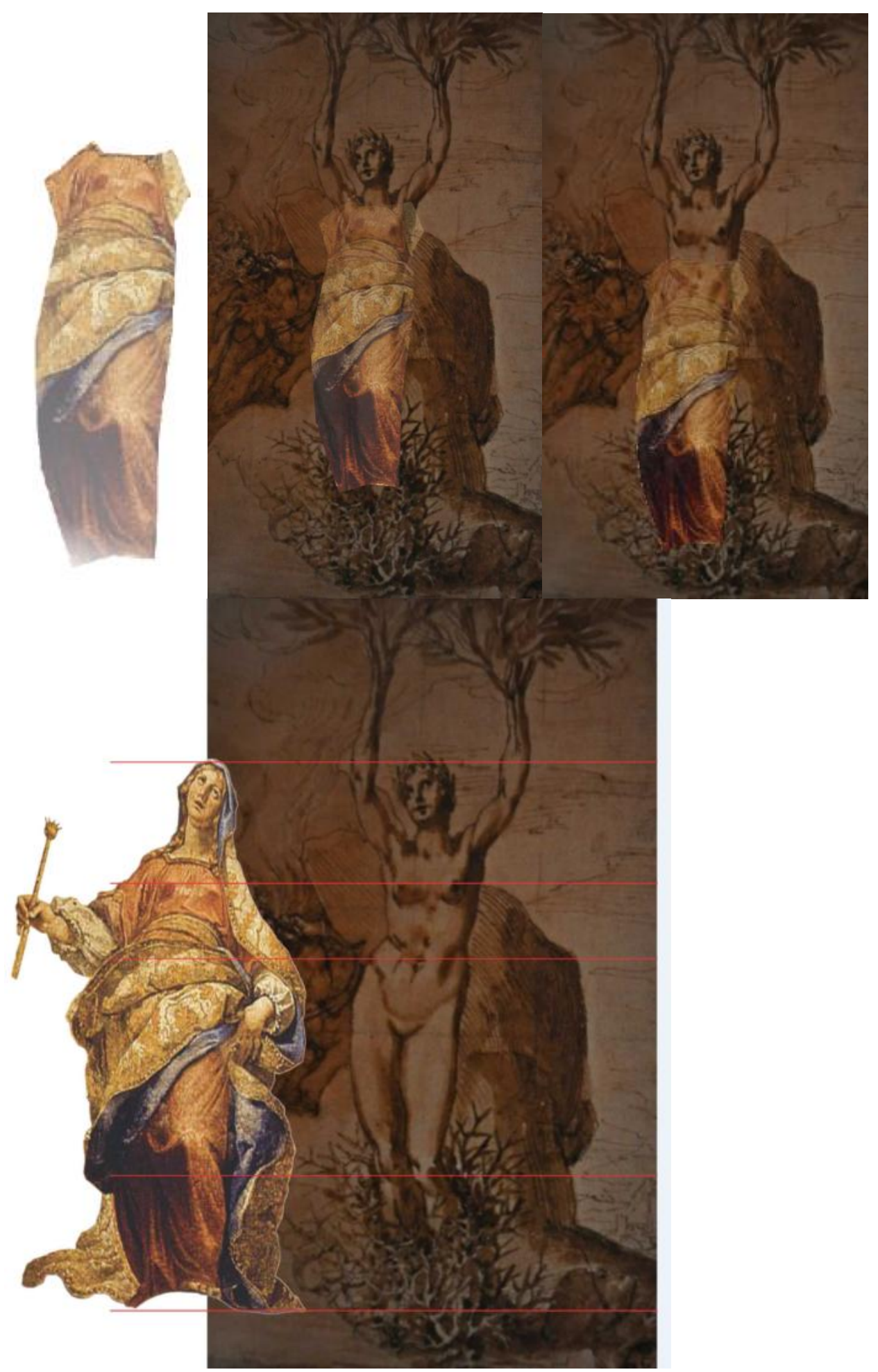

Figure 11. Comparison between Cigoli's Virtue and the Virgin 

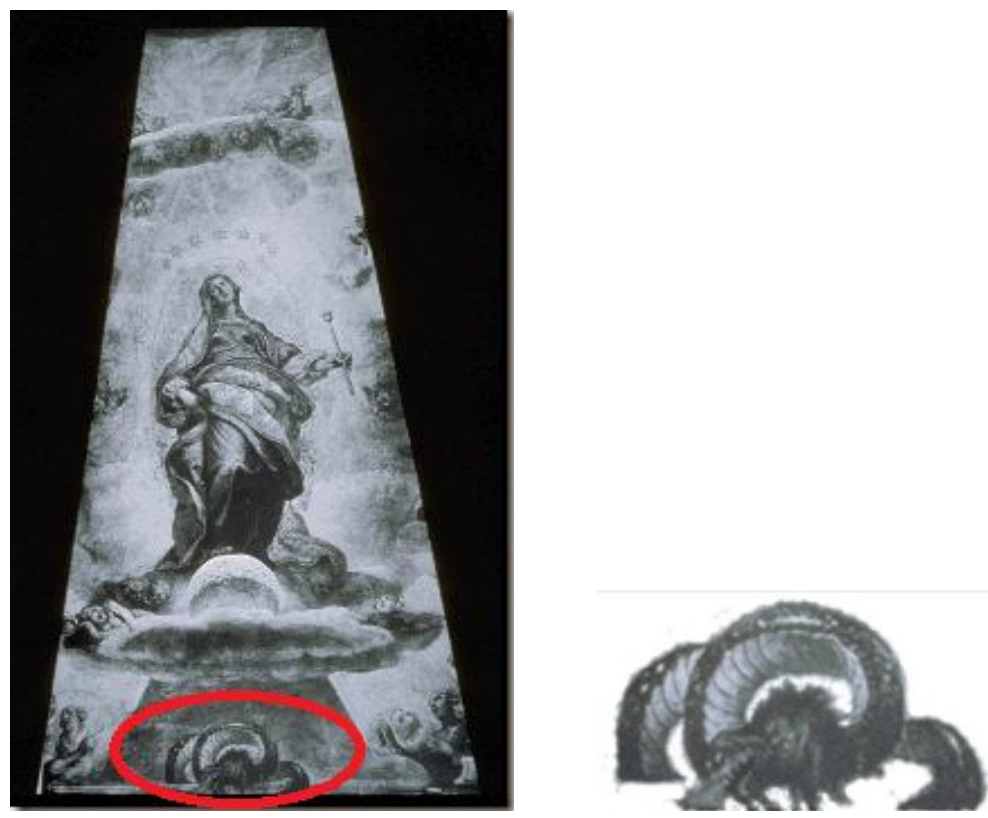

Figure 12. The Serpent

The latest "secret" of the Codex may be found in the lower section of the painting, below Galileo's telescopic moon: a dark cloud that seems to hide angelic figures. It may be suspected that these are not angelical faces but the acute eyes of felines. The whole structure forms a set of three possible types of cats which would be lynxes present throughout the whole history of the saga of telescopic discoveries. In fact, "lynxes" were the basis of the Accademia dei Lincei founded by the powerful maecenas Federico Cesi.

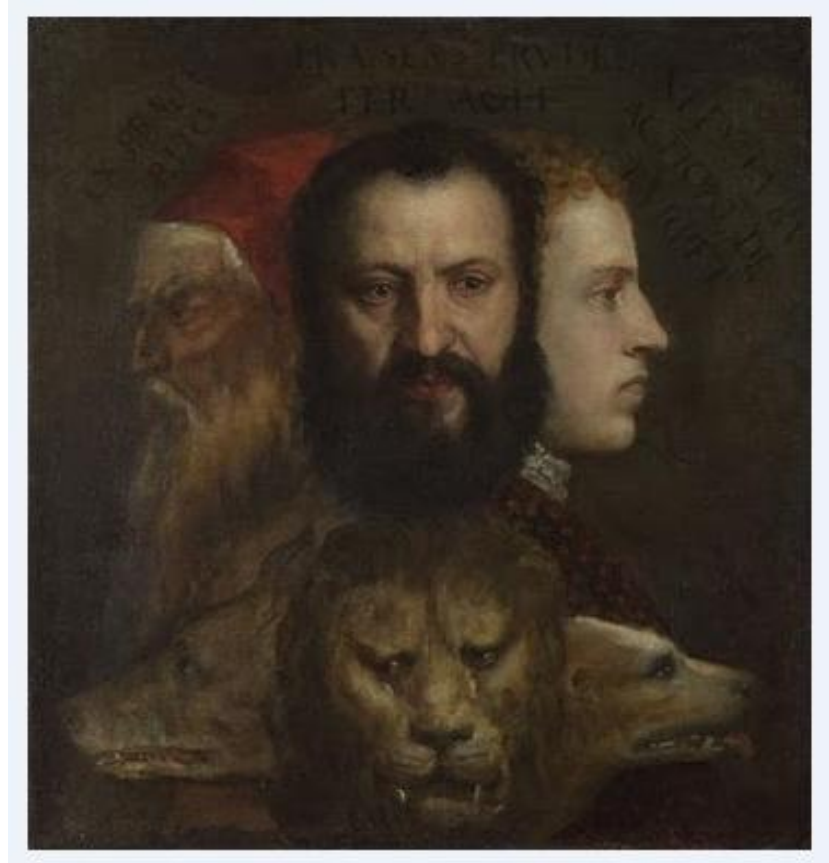

Figure 13. Titian's Allegory of Time 
Vol. 4, No. $3 \quad$ Neves et al.: Art and Science: Articulating a Contemporary...

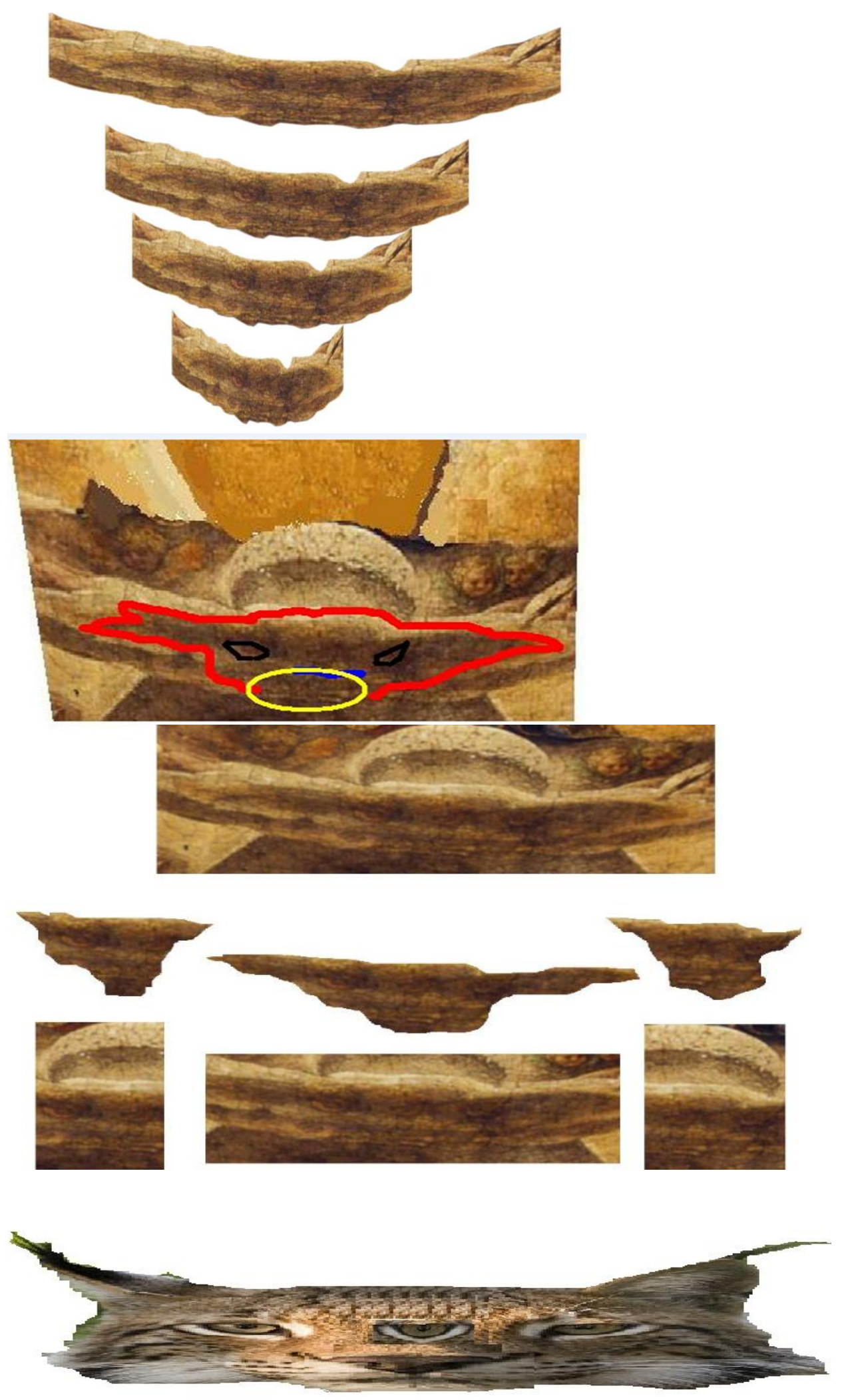

Figure 14. Set of Lynx-like Figures 


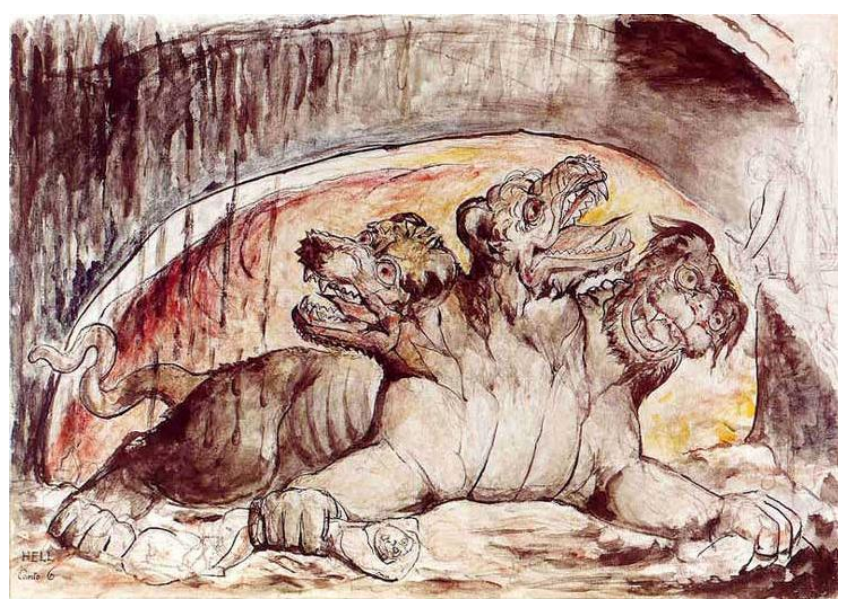

Figure15. Cerberus

\section{Conclusion}

Our gaze on the Art-Science approach derived from the complex relationships between Cigoli and Galileo may bring about a synthesis of the facts under analysis:

- Cigoli is an artist renowned throughout Italy;

- Galileo is a renowned scientist, the author of the great scientific work called Sidereus nuncius;

- Cigoli was engaged by pope Paul V to paint the Assumption of the Virgin in his chapel in the basilica of Santa Maria Maggiore;

- Cigoli maintains a lively and constant correspondence with Galileo, makes an observation on the moon and the Sun, follows the emerging scientific discoveries and paints sketches for his friend;

- Cigoli and Galileo have to face critics, intrigues, envious charges;

- Cigoli experiences the transition of artistic styles: almost everything was accepted and there was no need to maintain the Renaissance classical standards;

- Cigoli is not only Galileo's friend but participates in a society of cultured people from several fields of science: physicians, artists, writers and others. He shares in effervescent scientific and artistic experiences imbued with the new discoveries;

- Cigoli cannot make mistakes with his Virgin: he has to please the Pope. Contemporary artists were employing allegories which favored the possibility of presenting and representing facts and objects with covert meanings;

- Cigoli makes his Virgin present contemporary ideas and, consequently, Galileo's discoveries. The genius from Pisa does the 
same - one obtains the imprimatur from the Church and the other her authorization to paint frescos inside the dome of the Pauline chapel;

- Did Cigoli decide to work out an allegory? The present authors think that it is possible. They believe that the Virgin does not merely present symbols but it is a Codex...

The term Codex ends the section but opens wide and new possibilities so that the above conjectures and convictions could be confirmed or refuted.

\section{Acknowledgments}

Our thanks to "Fundação Araucária" and "Observatório da EducaçãoCAPES" for the financial support to our research area.

\section{Bibliography}

Bredekamp, Horst. "The Context of the Artists." Science in Context 14, no. S1 (2001): 153-192. Retrieved from goo.gl/OqcpSz. [Accessed: 20 April 2012]

Danhoni Neves, Marcos Cesar, \& Parrilha da Silva, Josie Agatha. Disturbing the Perspective: the new post-Copernican moon of Galileo and Cigoli. International Conference "Science \& Democracy," Napoli, Italy, 2008.

Galilei, Galileo. Mensagem das Estrelas (Message of the Stars). Rio de Janeiro: Museu de Astronomia e Ciências Afins/Salamandra, 1987.

Galilei, Galileo. Istoria e Dimostrazioni Intorno alle Macchie Solari (History and Demonstrations Around Sunspot). Roma: Edizioni Theoria, 1982.

Koyré, Alexander. Etudes d'Histoire de la Pensée Scientifique (History of Scientific Thought Studies). Paris: Presses Universitaires de France, 1966.

La Falda. XVIII Jornadas de Epistemologia y Historia de la Ciencia (XVIII Conference on Epistemology and History of Science), 2007. Retrieved from goo.gl/BX3f8D.

Owen, Richard. The Galileo Sketches that turned the Universe on its head. New York: The Times, 2007. Retrieved from goo.gl/cwhlRO. [Accessed: 20 April 2012]

Panofsky, Erwin. Significado nas Artes Visuais (Meaning in the Visual Arts). Transklated by M. C. F. Keese, and J. Guinsburg, $3^{\text {rd }}$ edn. São Paulo: Perspectiva, 2007. 